\title{
Kettős deficit \\ Magyarországon a 70-es és 80-as években
}

\section{Dual Deficit in Hungary in the 1970s and the 1980s}

Összefoglalás

A 70-es, 80-as évtizedben a külkereskedelmi hiány mellé nagy költségvetési deficit is társult. A folyamat megértéséhez két kérdés megválaszolása elengedhetetlen. Az egyik: „Volt-e oksági kapcsolat a kettő között? A másik: „Mi volt a kapcsolatuk a beruházási ciklussal?” Ezen kérdéskörök elemzése után a tanulmány megállapítja, hogy a beruházások ciklikus megugrása volt a közös ok mindkét deficit mögött. Az élénkülő beruházások, a termelés növekedése sok importot igényelt. A másik oldalon pedig a beruházások finanszírozása a költségvetés hiányát is megemelte. A beruházások visszafogásával átmenetileg mérsékelhető volt a behozatal, és a költségvetési kiadások is csökkenhettek. A költségvetés pozícióját javította az is, hogy az áremelésekkel megelőzték a fogyasztói ártámogatások terhének a növekedését. A külkereskedelemben gyorsabban sikerült a visszafogás, míg a költségvetési pozíció javítása ennél hoszszabb időt igényelt.

Journal of Economic Literature (JEL) kódok: E62, F32, F42, P21

Kulcsszavak: költségvetési politika, folyó fizetési mérleg, ikerdeficit, szocialista gazdaság

Prof. Dr. GidAY ANDrás, a közgazdaságtudományok kandidátusa (andras. giday@gmail.com). 


\section{Summary}

In the 1970s and 1980s, foreign trade deficit was accompanied by a high budget deficit. To understand the process, it is essential to answer two questions. One of them is: Was there a causal relationship between the two? The other is: How did they correlate with the investment cycle? After an analysis of these issues, it is concluded that the cyclical surge in investment was the common reason behind both deficits. Pick-up in investment projects and the increase in production required substantial imports. On the other hand, project financing also increased the budget deficit. By imposing restraints on CAPEX projects, imports could be temporarily reduced and budget expenditures could decline. The position of the budget was also improved by the fact that the burden of consumer price subsidies did not increased, due to the higher consumer prices. In foreign trade, curbing was faster, while the improvement of the budgetary position took longer.

Journal of Economic Literature (JEL) codes: E62, F32, F42, P21

Keywords: fiscal policy, current account, twin deficit, socialist economy

\section{Bevezetés}

Magyarország 1990-ben megörökölt tetemes külső adóssága az egyes években nagy értéket elérő külkereskedelmi hiányok miatt keletkezett. A jegybank, az általa felvett külső források zömét a költségvetésnek adta tovább, ezzel finanszírozták azt a magas keresletet, amelyik a túlzott importot eredményezte. Magyarországon a szocializmus alatti ciklikus gazdasági válságokat már a 80-as években is behatóan elemezték, az akkori elemzések azonban nem foglalkoztak a ciklus költségvetési hatásaival. Azóta pedig nem készült olyan mélyreható analízis, amelyik a költségvetés és a folyó fizetési mérleg együttes hiányát és ezek kapcsolatát elemezte volna.

E tanulmány a két évtizedes időszakban egymás mellé állítja a fizetési mérleg deficitet és a költségvetés hiányát. Az írás a „tyúk vagy tojás” dilemmára keresi a választ: a külkereskedelmi hiány okozta a költségvetési deficitet, vagy fordítva, a költségvetés túlköltekezése miatt következett be a külkereskedelmi hiány? Emellett arra is választ keres, hogy az ikerdeficitnek milyen kapcsolata volt a magyar beruházási ciklussal. Az elemzés felhasználta egyes évek költségvetési háttérszámításaiban található adatokat is. A tanulmány csak utal arra, hogy a költségvetési hiányban mekkora volt 1989 előtt a Magyar Nemzeti Bank (MNB) felé fizetett kamatterhek szerepe.

\section{AZ IKERDEFICIT AZ IRODALOMBAN}

A világ országait érintően sokszor elemezték már az ikerdeficit jelenségét. A fejlődő országok esetében például jó áttekintést ad Furceri és Zdzienicka (2018) tanulmánya. Az ikerdeficit említése miatt sok közgazdász már eleve a Nemzetközi Valutaalapra (IMF) és annak programjaira asszociál, és ez nem véletlen. Az IMF olyan leegyszerűsített modell alapján végezte az elemzését a 80-as évek végéig, amelyben szoros kapcsolatot feltételeztek a költségvetés és a 
fizetési mérleg folyamatai között. Ma már tudjuk, hogy a kapcsolat sok országban lazább, és azt is, hogy az 1-nél magasabb értékű költségvetési multiplikátor miatt a költségvetés radikális lefaragása még esetenként súlyosbíthatja is a helyzetet, mivel elmélyíti az adott országban a recessziót. Magyarországon a költségvetési hiány elemzése számára merőben új helyzetet teremtett Németh Miklósnak az a bejelentése 1989 novemberében, hogy a magyar állam adósságának az adatai torzítottak voltak. Az Állami Számvevőszék 1992-ben készített jelentésében bemutatta, hogy az egyes években mekkora volt az eltitkolt deficit, és ezen a bázison állapította meg az állam valós adósságát. A MNB 1993-ban készített elemzést az eladósodásról, melyben megadták az egyes évek valós költségvetési hiányait (MNB, 1993).

A témában járatos szakértők figyelmét a 90-es évek első felében a folyó költségvetési helyzet értékelése és az adósság piacosítása kötötte le. Később pedig 1997-ben a jegybanki devizatartozásnak a költségvetés általi átvétele volt az újabb, kielemzésre váró kérdés. Nem foglalkoztak az 1990 előtti költségvetés kérdéseivel az adósság IMF-orientációjú kezelését kritizáló szakértők, csak a külső adósság kialakulására és a lehetséges mozgástér feltérképezésére koncentráltak, illetve a beruházási ciklust elemezték (lásd: Soós, 1986; Bródy, 1983; Wiener, 1985).

\section{A CIKLUS SZOKÁsos LEFolyÁsA}

A válság általában azzal vált súlyossá, hogy a beruházások „elfutottak”, ráadásul a belső és a rubelpiacra is nőtt a termelés. Ezzel egyidejűleg (épp ezek miatt) tetemes importnövekedés jelentkezett a konvertibilis relációban. Emiatt gyakran részleges (vagy akár teljes) beruházási stoppot rendelt el a gazdaságirányítás, a konvertibilis relációban törekedtek az import fékezésére, illetve a kivitel növelésére, csökkentették a reálbérek növekedését, igyekeztek visszafogni a KGST-kivitel emelkedését. A mérsékeltebb építőipari igények miatt egy-két éven belül enyhült a beruházási piac túlfeszítettsége, a konvertibilis relációjú import fékezése miatt pedig javult a külkereskedelmi mérleg.

Három külső sokk erősen hatott a külső egyensúlyunk alakulására:

- cserearány-veszteségünk, mindkét relációban;

- élelmiszer-kiviteli lehetőségek visszaesése a Közös Piac korlátozásai miatt;

- nemzetközi pénzpiaci kamatok megugrása 1980-tól.

A hazai ciklikusság szakértői elemzői a beruházási hajlamnak és az emiatt magas konvertibilis külkereskedelmi hiánynak az elemzésére koncentráltak. A rubel relációjú egyenleg alakulását nem emelték ki, ez az akkori folyamatok ismeretében jogos is volt. Felvetődik a kérdés, hogy a magyar ikerdeficit szempontjából a dollár és rubel reláció együttesére vonatkozó teljes folyó fizetési mérleget kell-e egybevetni a költségvetési deficitekkel, vagy elegendő csupán a konvertibilis relációjú folyó fizetés mérleg és a költségvetés hiányainak az összevetése (1. és 2. ábra). A két görbepáros egy vonatkozásban tér el egymástól jelentősen, ez pedig a 1972-73as évek jelentős fizetésimérleg-többlete, a teljes forgalom figyelembevétele esetén. A 3. ábra mutatja az eltérés okát, a rubelforgalom jelentős kiviteli többletét ezekben az években (az ábrán a rubel és a konvertibilis relációjú külkereskedelmi egyenlegek és a nettó kamatkiadások alakulása szerepel). Két tényezőt érdemes kiemelni. Az egyik a rubelforgalom jelentős pozitív 
egyenlege, amely megmagyarázza, hogy a folyó fizetési mérleg miért tért el egymástól a 70-es évek első felében. A másik tényező a 80-as évtizedben a magas kamatkiadás, emiatt évi 3-4\%os konvertibilis külkereskedelmi többletet kellett volna GDP-arányosan felmutatni azért, hogy ne növekedjen tovább a külső adósság. A 1. ábrán látszik, hogy 1970 és 1990 között viszonylag szorosan együtt mozgott a költségvetési deficit és a dollár relációjú folyó fizetési mérleg hiány. Ettől eltérő volt azonban az 1974-75-ös időszak, mert ekkor a külső árak emelkedésétől ártámogatásokkal védte meg a költségvetés a termelőket.

1. ábra: GDP-arányos pénzügyi hiányok (folyó fizetési mérleg dollár-és rubelhiánya együtt, valamint az államháztartási mérleg deficitje (\%)

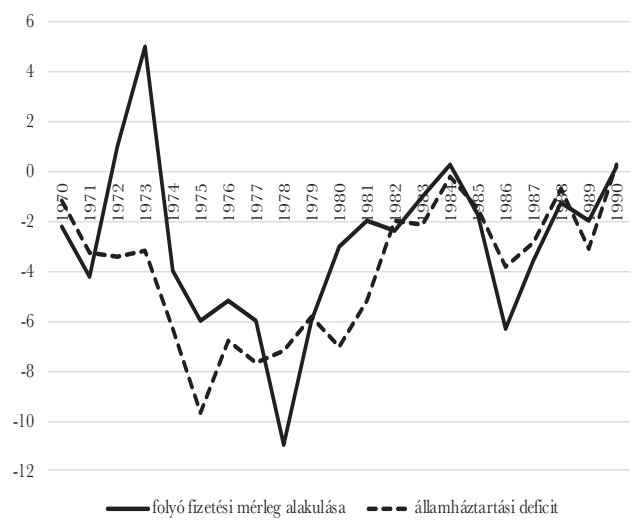

Forrás: fizetési mérleg: Kóczián, 2019; államháztartási deficit: KSH, ÁSz, MNB

2. ábra: Dollárviszonylatban kialakult folyó fizetési mérleg hiánya egybevetve az államháztartás hiányával (GDP\%-ában)

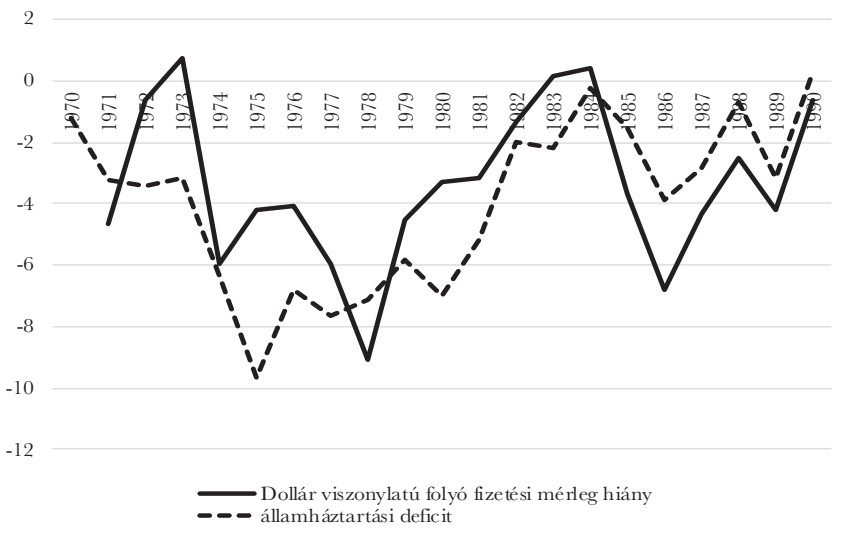

Forrás: ÁSz 1992; MNB, 1993 
A ciklus időbeli lefutása során a beavatkozások elsődleges célja egyrészt a beruházási gondok enyhítése volt, másrészt a konvertibilis relációban a túl magas import csökkentése (vagy a kivitel felemelése a magas importhoz). Az intézkedések hatásai általában gyorsabban jelentkeztek a külkereskedelemben, mint a költségvetési deficitben. A fejlesztések esetében maga a beruházási folyamat determinálta, hogy mikor várható eredmény (akkor, amikor befejezik az építést, vagy akkor, amikorra a beruházási stop miatt 1-1,5 év múlva lecsökken a kivitelezés alatt álló beruházások értéke). Meg kell jegyezni, hogy 1983-ig a döntések során általában nem nyomott erősen a latban az, hogy javuljon a költségvetés deficitje, és kisebb legyen az állam adóssága. Ami számított, az a nem rubel relációjú külkereskedelem deficitje és a beruházási piac túlfütöttségének az enyhítése. Dollár relációjú importot eredményezett a KGST és a fejlődő országok felé irányuló kivitel konvertibilis importigénye is. A fejlődő országok felé irányuló akkori kivitelünk magas hiteligénnyel járt. Ezek miatt még magasabb nyugati hiteleket kellett felvennünk. A KGST-be kivitt érték 15-17\%-a konvertibilis relációból behozott anyag, alkatrész stb. volt.

Az MNB számára a külső adósság kamatainak finanszírozása nagy feladatot jelentett, ezért 1981-82-től a vállalati hitelkamatokat magas szintre emelte. A kamat emelése negatívan érintette azokat az adósokat, akik korábban 6-8\%-os nominális kamatú hitellel vettek fel hitelt vagy fejlesztési kölcsönt. Hátrányos volt azoknak az ágazatoknak, amelyek rá voltak utalva arra, hogy a készleteiket hitelből finanszírozzák (pl. bútoripar, élelmiszeripar). A kamatemelés mellett akadt más, negatívan értékelhető MNB-lépés is. Ilyen volt a turista- és a kereskedelmi árfolyam egységesítése 1979-1980-ban. Ahelyett, hogy a jegybank felvállalta volna a várható IMF-kritikával szemben a kettős árfolyam megvédését, eltöröltette ezt a rendszert. Az átlagos devizakitermelési szintre beállított kereskedelmi árfolyamot tette egységessé ahelyett, hogy azt a határárfolyam felé mozdította volna el. A fentiekkel szemben az MNB pozitív hatású belépésére példa a konvertibilis exportot fejlesztő hitelcsomag és annak sikeres lebonyolítása a 70-es évek második felében.

3. ábra: A külkereskedelmi mérleg egyenlege rubel- és dollárviszonylatban, valamint a nettó dollárkamatkiadások a GDP\%-ában

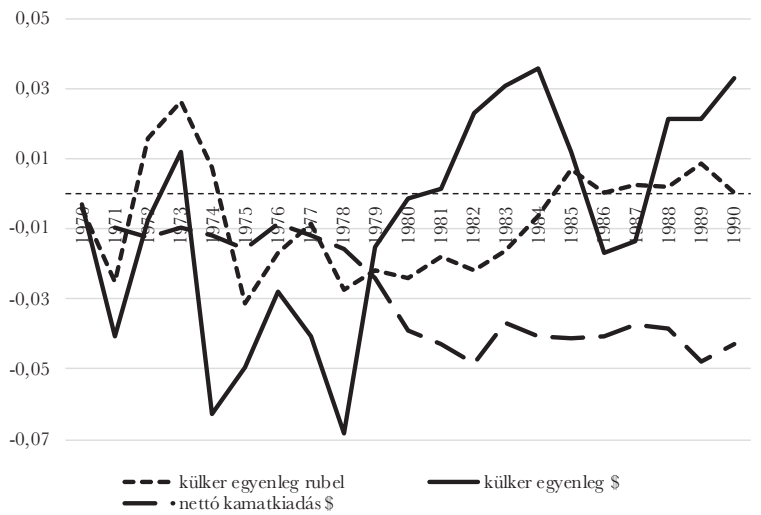

Forrás: Külkereskedelmi statisztikai évkönyvek, MNB, 1993; Lóránt, 1981 (Megjegyzés: Fuvarral együt) 


\section{A kiAdÁsoK És a BeVÉtelek VÁltozÁsa}

A következő pontokon a költségvetési kiadások rendszerjelleggel változtak. 1974-ben a megemelkedett világpiaci árak ellenére változatlan maradt az energiahordozók, anyagok ára, tetemes termelői ártámogatással (ezt a támogatást 1976-ra lecsökkentették). Az állami lakásépítés magas szintjéből 1981-től visszalépett az állam. Ezt helyettesítette azzal, hogy a kedvezményes OTP-kölcsönök viszonylag magas összegét a családi ház építéseknél is lehetett alkalmazni. A 70-es évek végén visszalépés következett be az állami nagyberuházásoknál (ez alól 1986-ig kivételt jelentettek az energetikai fejlesztések). A vállalkozások fejlesztési lehetőségeit erőteljesen visszafogták 1979-ben, az erre a célra felhasználható források megkurtításával. A fogyasztói ártámogatások relatív nagyságának (GDP-hez viszonyított értékének) a csökkentése 1984-től figyelhető meg. Az állami kiadások egyes tételeinél akadt példa automatizmus jelleggel fellépő növekedésre is. Ilyen volt 1987-88-tól az infláció felpörgése miatt az állami kamattámogatás megugrása a rögzített kamatozású lakossági kölcsönök után.

A bevételi struktúrában is változások következtek be. 1975-76-ban a termelői árak emelésével lecsökkent a vállalatok jövedelme, amelyet az eszközlekötési járulék csökkentésével kompenzált a kormányzat. 1980-81-ben bevezették az exportkövető árrendszert, amely növelte a vállalati szektor költségszintjét. Ennek ellentételezésére ekkor megszüntették az eszközlekötési járulékot. Ugyanakkor a világpiaci szintre emelt árak elvonták az alacsonyabb belföldi elóállítási, illetve KGST beszerzési árak közti különbözetet (ez volt a kütefa). Bevezették a szja-t és az áfát, és ezzel csökkenteni tudták az addigi magas vállalati adóterheket. Külső hitelre volt szükség mind a költségvetési hiány finanszírozásához (mivel nem volt ehhez belső megtakarítás), mind a külkereskedelmi hiány fedezése érdekében. A folyó fizetési mérleg egyik tétele, a külföld felé fizetett nettó kamat az 1979-től kezdődő időszakban évi 1 milliárd dollár körüli volt.

4. ábra: Az államháztartás éves kiadásai egybevetve a gazdálkodóktól származó bevételekkel és a beruházások alakulásával a GDP\%-ában

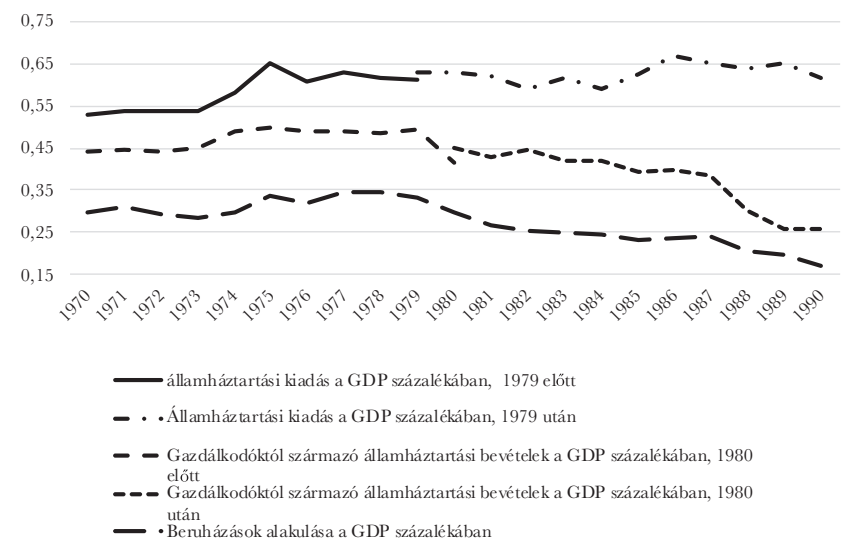

Forrás: Saját számitás Külkereskedelmi statisztikai évkönyvek alapján 
A 4. ábra egyik görbéje az államháztartási kiadások értékét mutatja (a GDP-hez viszonyítva). Látható, hogy a 70-es évek elején a GDP 53-55\%-át tette ki az állami kiadás, ez az érték 1974-től felszökött 62-65\%-ra, a 80-as évek elején 61-65\% volt. A mutatóról érdemes megjegyezni, hogy 1979-80-tól módszertani változás lépett be, ezért törés van a görbében. A társadalombiztosítási kiadások GDP-arányos értéke folyamatosan emelkedett. Ennek hátterében főleg a nyugdíjkiadások emelkedése állt, de a családi támogatások is jelentősen emelkedtek (a családi pótlékot 1989-ig a tb finanszírozta). A nettó kamatkiadás GDP-arányos értéke a 70-es évek közepén ment fel 1,5\%-os értékre, az azt megelőző évek 0,6-0,8\%-os szintjéről, a 80-as évek derekán is ezen szint körül mozgott. Ezeknek a kamatkiadásoknak kb. a harmadát/negyedét olyan tartozások után fizették, amelyeknél más volt a haszonélvező fél (pl. alapjuttatások, vállalatoknak adott állami kölcsönök). 1989-től az MNB felé fennálló minden tartozása után 6\%-os kamatot fizetett a költségvetés, majd 1990-től 7\%-ot. Az akkor kimutatott 450 Mrd Ft-nyi állomány után ez évente legalább 27-35 Mrd Ft-nyi kamat volt, azaz a GDP 1,5-2\%-a. Ezek fölött jelentkezett még a lakásépítési kölcsönök alacsony kamata miatti kamattámogatás. Ennek értéke a 70-es években a GDP 0,4\%-a volt, de az infláció miatt fokozatosan emelkedve, 1987-ben már az 1\%-ot közelítette, majd 1988-90-es időszakban $1,5-2 \%$ volt évente.

\section{Mozgástér a KÖLTSÉGVETÉSi ÉS A KÜLKERESKedelmi HiÁNy}

\section{MÉRSÉKLÉSÉHEZ}

A rendszerváltás előtt magas volt az állami újraelosztás mértéke. Elvileg ez akár lehetőséget is adhatott volna a költségvetési deficit lefaragásához akkor, amikor kiderült, hogy nagy a külső hiány, és elszaladtak a beruházások. A helyzet azonban nem volt ilyen egyszerű: egyrészt a gazdasági szférából elvont adónak, járuléknak a harmada csak azért kellett, hogy oda visszapumpálja a költségvetés, másrészt az egyik legnagyobb állami kiadási tétel a beruházás volt, ahol a visszafogásnak csak 2-3 év múlva lett jelentős hatása (átlagosan 4-5 év alatt készültek el a beruházások, az állami nagyberuházások esetében pedig nem volt ritka a 6-8 éves kivitelezési idő).

Ha megnézzük a 70-es, 80-as éveket a költségvetési egyenleg szempontjából, akkor a következő adódik:

- A beruházási visszafogásnak nagy szerepe volt a deficit lefaragásában. A 70-es évek közepén a GDP 2\%-ával csökkentették az állami beruházási kiadást. Az 1979 utáni öt évben pedig az újabb csökkentés a GDP-hez viszonyítva 5 százalékpont volt.

- Jellemző, hogy a „kiköltekezés” éveiben a tb-kiadások általában növekedtek (a GDP-hez viszonyítva). Viszont a visszafogás később ezeket nem érintette, hanem az elért magasabb szinten maradt az értékük. De csak addig, amíg nem következett be pár éven belül az újabb gazdaságpolitikai lazítás időszaka, mert akkor ismét tovább emelkedett a ráta.

- Az oktatási kiadások szintje emelkedett a 80-as évek első felében és közepén (dacára annak, hogy akkor egy hosszú visszafogási periódus volt).

- A vállalati szektorral szemben a költségvetés vagy az elvonások növelésével, vagy a támogatások csökkentésével tudta javítani a pozícióját. 4-5 évente újraszabták a vállalati gazdálkodás 
szabályozóit és az árfeltételeket, ekkor az elvonásokat is módosították, és az árakat is változtatták. Ennek során a döntő szempont a vállalati szektor pozíciója volt, az, hogy a cégeknek mennyi forrásuk lesz beruházások, készletek finanszírozására, mennyire tudják emelni a kereseteket. Az másod- vagy harmadrangú probléma volt, hogy maga a költségvetés egyenlege mennyivel javul. Az ár- és szabályozó alku során a vállalatok a hatékonysági tartalékaikról nem tettek említést, viszont 1-2 éven belül ezeknek a mobilizálásával a vállalati jövedelmek a vártnál jobban emelkedtek. Azaz a tervben, a költségvetésben leírthoz képest többletforrások keletkeztek, amelynek az elköltése a beruházási többleteket, a vártnál nagyobb keresetemelést stb. eredményezett. Az állam pedig „,futhatott a pénze után”, azon gondolkozva, hogy miként csökkenti a vállalati jövedelmeket. Erre 2-3 éven belül sor is került, vagy úgy, hogy egyoldalú áremelésekkel növelték a költségeket (és így kisebb lett a nyereség), vagy úgy, hogy megemeltek egyes adókat. A támogatások csökkentésére csak akkor került sor, amikor az árakat is módosították (általában ekkor beépítették a támogatást az árba).

- Cisak néhány évben (1979-80, 1988-89) alkalmazott módszer volt az, hogy a vállalati szektortól jelentős nettó adósságtörlesztést vártak el (nagyobb törlesztést, mint amekkora az új hitelek folyósítása volt). Így csökkent a vállalatok beruházásra, készletezésre fordítható jövedelme. Ekkor ezt a forrást (az ún. országos hitelmérleg közbeiktatásával) a költségvetés használhatta fel a hiánya finanszírozására.

- A lakossági reáljövedelmek jelentős csökkentése esetén a költségvetési deficit kisebb lett (mert ekkor csökkentették a lakossági ártámogatásokat). Ilyen intézkedésre két ízben kerítettek sort, először 1979 nyarán, a fogyasztói árak 16\%-os emelésével, másodszor pedig az 1988-as adóreformmal (16\%-os infláció 1988-ban). Mindkét esetben a következő 2-3 évben is az előző szint alatt maradt a reálbér. Figyelemre méltó egyébként, hogy a külkereskedelem valóban jelentős javulására mindig az ilyen drasztikus lakossági áremelést követő egy-két évben került sor.

A költségvetési deficit alakulására a külkereskedelem hiány mérséklése ellentétes irányú hatást gyakorolt. Az export növelése az exporttámogatás összegét emelte. Az importcsökkenés pedig bevételkiesést eredményezett (vámok és illetékek). A fenti kettő közvetlen hatás együttesen a GDP 1,2-1,8\%-ával egyenlő értékben növelhette az állami deficitet egy kiigazítás két-három éves időszakában. Ezen közvetlen hatások mellett persze közvetett hatások is jelentkeztek, mindenekelőtt az importnál. Az import csökkentése ugyanis visszafogta a termelés bővülését, ami a vállalati szektortól beszedhető adók, járulékok összegét mérsékelte. A nagy külkereskedelmi hiány lefaragása tekintetében mozgástér a következőkben kínálkozott. Mivel a magas import éveiben a behozatal jelentős hányada a készletállományt növelte, a visszafogás nem veszélyeztette jelentősen a folyó termelést, ugyanis a következő egy-két évben fel lehetett használni a magas anyagkészletet. Az 1976-78. évi konvertibilis import többlete mintegy egyharmad részben a készletek növekedését táplálta (Boda, 1981). A belföldi felhasználás csökkentése esetén visszafogottabb lett az importigény, 1978-81-re a behozatali többlet csökkentésének a 80\%-a mögött a belső kereslet visszafogásának a hatása állt (Juhász, 1982). A 70-es évek viszonylag liberális (konvertibilis relációjú) importengedélyezési rendszere miatt rövid távon behozatalcsökkentést lehetett elérni az importengedélyezés radikális szigorításával. Ezzel élt is a kormányzat 1980-tól, amellyel elérték azt, hogy 1980 után a vállalatok nem tudtak jelentős összegű importkészletet felhalmozni. 


\section{AZ EGYES CikLUSOK Jellemzése}

Az alábbiak a külkereskedelmi és az államháztartási mérleg szempontjából jellemzik az egyes ciklusok gazdasági folyamatait.

\section{0-1973}

Ezt az időszakot a későbbi korszak hektikus kilengéseihez viszonyítva az egyensúly aranykorának is nevezhetjük. Ekkor is lezajlott persze egy szokásos ciklus, amelyet az jellemzett, hogy 1971-ben megbomlott az egyensúly a beruházási piacon, mivel túl sok beruházás indítására került sor. Ezzel egyidőben nagyarányú volt a készletfelhalmozás is (a termelés biztonsága érdekében). A fentiek következtében megugrott a tőkés import 1971-ben, nagy deficit alakult ki ebben a relációban. Erre válaszul erősen korlátozták az indítható beruházások számát és értékét, egyre több terméket vontak az ún. keretgazdálkodás alá (energiahordozók és az abból készített termékek, hengerelt áruk stb.). 1972 és 1973 során sikeres volt az egyensúlyi helyzetre való visszabillentés: a készletnövekedés csökkent, a beruházások befejezetlen állománya alig nőtt, a kedvező nyugati konjunktúra kihasználása révén 1972-73-ban nőtt a kivitel, és 1973-ra aktívum alakult ki. Ebben az időszakban következett be a szabályozási visszafordulás, ugyanis 1973-ban kijelölték az 50 legnagyobb ipari vállalatot azzal a szándékkal, hogy a központi vezetés ,kiemelt figyelemmel” kísérhesse őket.

1970-re jelentős bérszintbeli különbségek alakultak ki (1968-tól) egyes vállalatcsoportok között, ezért 1971 -től lazították a kapcsolatot a nyereségszint és a béremelés lehetősége között. Ugyanakkor a nyereségesség javítását nagyobb béremelési lehetőséggel honorálta a rendszer. 1973 májusában központilag döntöttek a nagyipari munkások béremeléséről, ami 8\%-os ipari és $6 \%$-os építőipari béremelést jelentett. A vizsgált időszakban teljesedett ki az ötnapos munkahétre való átállás.

A szabályozók 1971. évi változtatását követő időszakban bekövetkezett az ilyenkor szokásszerű eltolódás a vállalati szektor által felhasználható jövedelmek irányába, a központ rovására. Rubel relációban 1970 után erősen emelkedett a kivitel, és 1972-1973-ban jelentős aktívum jött létre, amely még 1974-ben is fennmaradt. A rubelbehozatal növelése érdekében kedvezményes hitelt adtak azoknak a cégeknek, amelyek erről a piacról behozott berendezéseket vásároltak. Az árfolyamok nem változtak. 1972-73-ban kedvező volt a konjunktúra Nyugat-Európában, amelyet a magyar vállatok sikeresen ki tudtak használni, 1973-ban például 21\%-kal lett magasabb a kivitel volumene ebben a relációban.

\section{4-1978}

Az 1974-78. évi időszak erős külső sokkal köszöntött be. Az arab-izraeli háború után megugrottak a világpiaci olajárak, amelyet a nyersanyagárak emelkedése követett. A magyar gazdaság 20\%-os cserearányromlást szenvedett el a konvertibilis relációjú külkereskedelmében, ami éves szinten 300 millió dollárral emelte meg az importszámlát. A gazdaságpolitika ennek ellenére nem változtatott a belső árakon, amely 40 milliárd forint importár-támogatással volt 
csak lehetséges 1974-ben.

Késve, csak 1975-76-ban lépett a gazdaságpolitika. Egyrészt sok nyersanyag és energiahordozó árát a meghatározó tőkés importárakhoz igazította, azaz felemelte, másrészt az így emelkedő termelési költségszint miatt csökkentette az elvonásokat. A megbomlott külső egyensúly miatt 1975-76-ra visszafogottabb termelési célokat jelöltek meg, azt remélve, hogy ez idő alatt érezhetően javíthatják az egyensúlyt. Ez a cél csak az első évben teljesült. Az 1975 decemberében elfogadott 1976. évi terv már újra magasabb növekedési ütemet célzott meg.

A beruházások az 1975-ös nyugalmi időszak után 1977-78-ban igencsak elfutottak, megnőtt a befejezetlen beruházások állománya, késedelmes volt a kivitelezés. A készletek úgyszintén nagymértékben emelkedtek. Az átmeneti javulás után 1978-ra tetemes külkereskedelmi passzívum alakult ki, a hiányok miatt tőkés bankoktól kellett nagy összegü hiteleket felvenni. A GDP növekedése ugyan stabilan évi 5-6\%-osnak látszik a KSH adatai alapján, valójában 1974-től megtört a növekedés, mert jelentős cserearányromlás következett be, mely az adott év GDP-növekedésének nagyobb hányadát „elvitte”. Látszott, hogy a szokásosnál sokkal drasztikusabb visszafogásokat kell majd foganatosítani. 1976-tól már nem kezelték abszolút tabuként sem az alacsony inflációt, sem az évente jelentős reálbér-emelkedést. Ezt jelezte, hogy 1976 májusában hatósági áremelésre került sor a hús- és a tejtermékek piacán.

A cserearányromlás az első két esztendőben (1974-75) a tőkés relációban jelentkezett, majd 1976-tól a KGST-kapcsolatokban is. A gazdaságpolitika a magasabb külső inflációtól úgy „védte” a magyar gazdaságot, hogy a termelői árak nagyobb változtatása során felértékelték a forintot a tőkés valutákhoz képest, de volt, amikor a rubelhez képest is. 1978-ban a Szovjetunió 850 millió rubeles hitelt adott ahhoz, hogy a magasabb energiaárakat, nyersanyagárakat a magyar fél ki tudja fizetni, és a hitelt Magyarország áruszállítással törlesztette. Ezért a rubel relációjú kivitelt dinamikusan emelték, több évben is külkereskedelmi aktívumot értünk el. Ennek a kivitelnek a növelését a fejlesztési programok új kapacitásai is segítették.

A 70-es évek közepétől sikeres hitelkonstrukciót működtetett az MNB (meghirdetésekor 45 milliárd Ft összeggel) azon fejlesztések finanszírozására, amelyek növelték az exportot. Ez pár év múlva éves szinten 1 milliárd dollárral növelte a nettó exportot (Doros, 1980).

\section{9-1984}

Ebben az időszakban három drasztikus lépéssorozatra került sor. Egyrészt erősen visszafogták a beruházásokat, másrészt nagy lakossági áremelésre került sor, harmadrészt pedig kötött devizagazdálkodásra tértek át. A lakossági áremelések két évre reálbércsökkenést eredményeztek. A beruházások volumene 1980-tól minden évben csökkent, az 1979-es 33\%-ról 24\%-ra esett a beruházási ráta. Az állami lakásépítéseket visszafogták. A kötött devizagazdálkodás bevezetésével pedig elejét tudták venni a vállalati szektor nagyarányú készletfelhalmozásának. Ezen túlmenően a kormány energia- és anyagtakarékossági programokat is hirdetett, amelyekhez állami támogatást biztosított. Az időszak eredménye volt a visszafogott import révén a külkereskedelmi egyenleg javulása, továbbá a fajlagos energiafelhasználás csökkenése. 1979től az új állami beruházások indítását korlátozták. A vállalati forrásokat azzal csapolták meg, hogy megemelték a kötelező tartalékalap-képzést, a nyereség 15\%-áról annak 25\%-ára, a fej- 
lesztési forrásokra ható kedvezményeket pedig csökkentették. 1980-tól új árrendszerre tértek át, amely az exportárakhoz igazította a belső árakat. Az így számottevően megemelt árak és az ennél alacsonyabb import, illetve a hazai beszerzési árak között jelentős volt a különbség, ez teljes egészében befizetésre került a költségvetésbe.

Az ipari termelés már csak 1-3\%-kal emelkedett évente, sőt az egyik évben visszaesés is történt. A költségvetési hiány a 6-7\%-os szintről fokozatosan 2\%-ra csökkent (a GDP-hez viszonyítva). Ebben nagy szerepe volt a biztos bevételt hozó kütefa 1980. évi bevezetésének. A konvertibilis export ösztönzésére adott addigi támogatások egy részét 1980-tól átkeresztelték kütefa-visszatérítésre, amelyet a GATT-tal is elfogadtatott a magyar fél.

A lakossági fogyasztói árakat mintegy 16\%-kal megemelték 1979 nyarán. Az ezt követő években is legfeljebb a reálbérek szintjének a megőrzését hirdették, és nem annak növelését. A reáljövedelmek valamelyest emelkedtek 1981-től, mert a társadalmi juttatások egyre kiterjedtebb kört értek el (nyugdíjasok számának az emelkedése, családi pótlék stb.). Számos területen lehetőséget adtak bértömeg-szabályozásra a 70-es évek második felétől. Ugyanis a foglalkoztatottak száma demográfiai okok miatt csökkenő volt.

1981-től a vállalatok a konvertibilis relációból beszerzett anyagokhoz, gépekhez csak akkor tudtak hozzájutni, ha a külkereskedelmi tárca által felügyelt, a korábbinál jóval szigorúbb rendszerben engedélyt kaptak az importra. A legfontosabb szempont az volt, hogy a cég mennyivel tud hozzájárulni a konvertibilis relációjú kivitelhez.

1981-ben a Szovjetunió másfél millió tonnával csökkentette az évente általa szállított kőolajat. Ez krízissel felérő helyzetet teremtett az energiaigényes magyar nehézipar számára. Ebben a helyzetben a kormányzat energiamegtakarító programot hirdetett, pár év alatt érezhetően csökkent az ipar által felhasznált energia. A másik oldalon pedig a 80-as évek legelején gőzerővel folytak az energetikai beruházások, a hazai energiabázis megerősítése céljából. A visszafogott import miatt a kivitelben elért eredmények a konvertibilis külkereskedelem javulását eredményezték a 80-as évek első felében. Ebben fontos szerepe volt a dollár elszámolású magyar-szovjet hús-gabona konstrukciónak is. A 80-as évek elejétől az addigi szállítási szint feletti gabona és hús esetében dollárban fizetett a szovjet fél, pontosabban kőolajat szállított devizáért, világpiaci áron.

Annak érdekében, hogy mérsékeljék az új árrendszerre való áttérés miatti inflációt, most is a forint felértékelésének a módszerét alkalmazták, összességében még így is 22\%-os volt a termelői árak emelkedése 1981-82-ben. A kütefa beszedése lehetőséget adott a vállalati elvonások csökkentésére, erre szükség is volt, mert a megemelkedett költségszint csökkentette az elérhető jövedelmet, megszűnt az eszközlekötési járulék és az illetményadó. 1981-84-ben a vállalatok egyes alapjait érintően a zárolás, elvonás eszközével is élt a kormányzat, nehogy túl sok forrásuk legyen beruházásra. Ebben az időszakban jelentősen lecsökkentették az állami bérlakásépítést, a korábban elindított építési programok folytatásakor már nagyrészt a magántulajdonú konstrukciót alkalmazták. 1983-tól a családi házak építése jelentősen emelkedett amiatt, mert a családi házat építő párok számára is elérhetővé vált a magas összegü kedvezményes kölcsön, illetve szociálpolitikai támogatás (ezek addig csak a telepszerű építések esetében voltak elérhetőek). 
A hitelezés a beruházási visszafogás kiszolgálója lett 1979 után. Egyrészt elrendelték, hogy új beruházáshoz ne nyújtsanak hitelt, csak a gyors kivitelezésű konvertibilis kivitelt növelő fejlesztés volt kivétel ez alól. Másrészt a hitelező (a monobank, az MNB) arra törekedett, hogy lekösse a vállalatok szabad fejlesztési forrásait, ennek fö eszköze az ún. forgóalap-feltöltés volt. Amennyiben a cég fejlesztési alapjában volt pénz, akkor a bank vizsgálni kezdte, hogy a tartós készletállományát miből finanszírozza. Ha a többletforrás egyik oka az volt, hogy a korábbi banki hitelkérelemben jelzettnél magasabb lett a vállalat jövedelme, akkor a bank sok esetben azt mondta ki, hogy ezt a tartós forgóeszközhitel előtörlesztésére kell fordítani.

1984-től áttértek az új vállalati formákra, vállalati tanácsok alakultak az állami cégek zöménél. 1981-től a bérszabályozás kötöttségei mellett új lehetőségként egy kisebb lazítást vezettek be, a vállalati gazdasági munkaközösségek alapítását. Ezt viszonylag széles körben alkalmazták a vállalatok. Ennek előnye a kereseti kiadásokkal szemben az volt, hogy költségként lehetett elszámolni az ilyen kiadást a cégeknél. Az ilyen elszámolásnak a lehetősége 1988 januárjában szűnt meg, ami a vállalati gazdasági munkaközösségek tömeges felszámolásához vezetett.

\section{5-1990}

1984 decemberében hirdette meg a politika az élénkítés programját, 1985-től kezdődően. Az első két év (1985-86) együttesen 4\%-os reálbér-emelkedése hozzájárult az egyensúlyi pályáról való lecsúszáshoz. A korábbi élénkítési időszaktól eltérően ebben a ciklusban csak kisebb szerep jutott a beruházásoknak. 1986-87-ben együttesen 10\%-kal emelkedett a beruházási volumen, amely jóval elmaradt az 1970-71. évi 29\%-os vagy az 1977-78. évi 18\%-os emelkedéstől. A vizsgált periódusban a beruházási ráta átlagosan 21\%-os volt (az előző évtized szintjétől jóval elmaradt). Ebben a két évben, 1985-86-ban a behozatal 13\%-kal nőtt, ettől elmaradt a kivitel emelkedése. Az ipar összességében 7\%-kal emelte a termelését az időszak alatt.

Új szabályozórendszert vezettek be 1985-ben, amelynek fő eleme az egységes érdekeltségi alap volt, az egyes felhasználási célokra kivetett, célzott adókkal szabályozták ennek az elköltését (felhalmozási adó, kereseti adó). A bérszabályozás mértékeit úgy állították be, hogy a jövedelmezőbb vállalatok keresetemelési lehetősége jelentős volt. Kiugróan, nominálisan 8,4\%-kal emelkedett 1985-ben az átlagkereset, ami a reálbérek növekedését jelentette. 1986ban megismétlődött az, hogy viszonylag (a tervhez képest) magas lett a keresetek emelkedése.

Az első két évben volt ugyan némi GDP-emelkedés, de ezt „elvitte” a cserearány-veszteség. 1985-ben a gazdálkodás külső feltételei sem voltak kedvezőek: egyrészt jelentős aszály volt, másrészt az 1985-ös csernobili katasztrófára hivatkozva a nyugati vevők csak a szokásosnál alacsonyabb áron voltak hajlandóak megvenni a magyar élelmiszereket, harmadrészt pedig a szokatlanul hideg tél 300 millió dollár többletimportot okozott. Az 1985-ös évben 500 millió dollárral romlott a konvertibilis külkereskedelmi egyenleg, 1986-ban pedig újabb 300 millió dollárral.

A vállalatok 1985-ben az emelkedő forrásaikat elköltötték a keresetek emelésére és beruházásra, így a konvertibilis külkereskedelem 1981 óta először újra passzívumot mutatott. Mivel az elosztható GDP nem emelkedett, nemcsak a külső pozícióban, hanem belföldön is 
meg kellett jelennie valahol a hiánynak, ez okozta a költségvetési deficit megugrását. A vártat meghaladó 1985. évi költségvetési hiány mögötti egyik fontos ok a rubel elszámolású cserearányok változása miatt csökkenő kütefa-bevétel volt, a másik pedig a pénzintézetek vártnál alacsonyabb nyeresége, amely miatt csökkent a tőlük beszedett nyereségadó.

1986 őszén 8\%-kal leértékelték a forintot, amelynek érdekessége volt, hogy ekkor speciális technikával elkerülték, hogy az exportárkövető rendszer miatt automatikusan emelkedjenek a belföldi árak. 1987 tavaszán aztán hivatalosan is bejelentették, hogy megszűnt az exportárkövetés addigi rendszere, helyette piaci árakra tértek át. Így az ekkori újabb 8\%-os leértékelés mintegy 4 százalékponttal emelte a termelői árakat, a tovagyűrűző kétéves hatása alatt.

Az élénkítés kudarca miatt 1987-re már az egyensúly javítását helyezték előtérbe. Az éves tervben a termelés olyan mérsékelt, 2\%-os növekedését hirdették meg, amely mellett egyrészt szinten marad a belső felhasználás, másrészt a konvertibilis relációban az egyenleg nullszaldóssá javul. A termelés növekedése be is következett, de a belső felhasználás mindkét fő eleme (lakossági fogyasztás, beruházás) is ehhez hasonló ütemben, 2\%-kal növekedett. A külkereskedelem passzívuma csökkent ugyan, de nem szűnt meg. Amennyiben a céloktól való elmaradás okait keressük, akkor a nyereség vártat meghaladó növekedését, az 1988-as adóreform miatt előrehozott lakossági vásárlásokat és a feltételezettnél gyengébb exportképességet lehet megjelölni. 1987-ben ugyan a reálbérek 1\%-kal csökkentek, de a nyugdíjak és más pénzbeli tb-juttatások miatt a reáljövedelem összességében szinten maradt, ugyanúgy 9,3\%-kal nőtt, mint a fogyasztói árak.

Jelentős volt 1987-ben a beutazó turizmusból származó bevétel. Konvertibilis relációban ez 370 millió dolláros aktívumot mutatott (rubel relációban pedig 300 millió rubelt). Rubel relációban a külkereskedelmi egyenleg is többletet mutatott, amit az itt fennálló adósság törlesztésére fordítottak. Az államháztartás hiánya a vártnál kisebb lett, mert a kütefa-bevétel jelentős, 15 milliárd Ft-os többletet mutatott, viszont ettől elmaradt a vállalatoknak nyújtott támogatások összegének az emelkedése (7 milliárd Ft).

1987-89-ben a nem rubel elszámolású kivitel jelentős sikereket ért el, kihasználva az akkor erős nyugat-európai konjunktúrát. A dollár elszámolású magyar külkereskedelem deficitje az 1986. évi 470-ről 1987-ben 320 millió dollárra mérséklődött, majd 1988-ban közel 500 millió dollár exporttöbblet keletkezett, 1989-ben pedig 600 millió dollár körüli lett ez az aktívum. A kedvező eredmények hatását azonban lerontotta a világútlevél 1987. év végi bevezetése nyomán kialakuló bevásárlóturizmus. A szektor konvertibilis devizaegyenlegének a szokásos aktívuma passzívumba váltott át 1988-ban. Rubel relációban az export-import pénzügyi hidak egyenlege negatív volt.

1987 januárjától kétszintű lett a bankrendszer, az MNB-ről levált három kereskedelmi bank. Az első évben viszonylagos likviditási bőséggel rendelkeztek. 1988-ban azonban az MNB meghirdette a hitelcsökkentést, és jelentős jövedelmet szivattyúzott ki folyamatosan a bankszektortól, ez volt a magas hitelkamatok egyik fő oka. A betétek mintegy 15\%-át kötelező volt elhelyezni a jegybanknál, amely erre kamatot nem adott. Ezzel szemben a bankoknak 1987 közepétől legalább 15\%-os, 1988 közepétől pedig 20\% feletti kamatot kellett adniuk a betétet elhelyező ügyfeleknek. A kereskedelmi bankoknak mindez akkor évi 40-50 milliárd Ft-ba került, ami a GDP mintegy 2\%-a, tekintélyes érték. 
1988-ban került sor az adóreformra, a két új adónem, az szja és az áfa bevezetésére. A termelői árak az átállással 3\%-kal csökkentek. Az energia- és nyersanyagigényes termékek árai alig változtak, ezzel szemben a feldolgozóipar termelői árai nem csökkentek. A munkaigényesebb szolgáltatások árai pedig érezhetően nőttek. A bérek kötelező bruttósításával teremtettek fedezetet a vállalatok ahhoz, hogy meg tudják fizetni a dolgozóik keresete után az szja-t, és így ne csökkenjen a nettó bérek nominális értéke senki számára sem. Az adóreformot kísérő fogyasztóiár-emelkedés is hozzájárult a reálbérek csökkenéséhez, ez 3 év alatt együttesen $7 \%$-os volt.

Az adóreform lehetőséget adott a fő jövedelemtulajdonosok jövedelmeinek az átrendezésére. A vállalati adóknak az új adókkal való helyettesítése mellett az alapcél a vállalati nyereség 40\%-os csökkentése volt, amely esetén az állami centralizáció mértéke csökkenthető volt. Ezzel az egységnyi jövedelemből kevesebbet kellett befizetni a költségvetésbe, és magasabb hányad maradhatott a cégeknél. Ugyan nem sikerült maradéktalanul elérni a számszerúen megfogalmazott célokat, de mégis elmondható, hogy az új helyzet a korábbitól lényegesen eltérő feltételeket hozott. A vállalati szektortól beszedett adók GDP-arányos szintje csaknem a harmadával csökkent 3 év alatt, az 1987. évi 38\%-ról 1990-re 26\%-ra csökkent le. A csökkenés főleg a megszűnt adónemek miatt következett be.

A kiadási oldalon jelentősen csökkentek a vállalati szektor támogatásai. Az államháztartás kiadásainak a GDP-arányos értéke az 1987. évi 65\%-ról lecsökkent, egészen a 61\%-os szintig, 1990-ben. Ebben a folyamatban egyik fontos elem volt az ártámogatások csökkentése, ezek értéke 1987-ben még a GDP 8,2\%-át érte el, 1990-re viszont már csak ennek a felét, 4,1\%-ot. Az ártámogatás megszűnését általában az árak arányos emelkedése követte, amelyet a fogyasztó vagy megfizetett, vagy nem, de a lényeg, hogy egyikük sem fordult a költségvetéshez az árak támogatása érdekében (ha mégis, akkor elutasították azt). Az adóreformmal átrendeződött az államháztartás szerkezete is: mivel az szja zöme tanácsi bevétel lett, ezért a költségvetés jelentősen csökkentette a támogatását a tanácsi szféra felé. Az inflációs folyamat a kiadásokat is átrendezte: egyrészt a betétikamat-emelkedés miatt az államra háruló lakossági kamattámogatás a háromszorosára nőtt 1987-től 1990-ig, másrészt viszont az állam a kereskedelmi bankok magas kamatjövedelme miatt tekintélyes nyereségadó-bevételre tett szert 1988-tól. A gazdaságpolitikai szemléletváltás hatása is érződött a kiadási oldalon. Csökkentek az ártámogatások, és az állami beruházási kiadások reálértéke egyre kisebb lett. Az szja és az áfa bevezetése miatt az adók kimutatott összege csupán az elszámolási módszer miatt is emelkedett.

Ezen felül technikai változásra is sor került az államháztartás egyes rendszerei között. A költségvetés és a tb-alap között feladatcsere zajlott le 1990 tavaszán. Az állam átvette a családi pótlékok finanszírozását, viszont a másik oldalon átadta a tb-nek az egészségügyi kiadások finanszírozását, annak járulékfedezetével együtt.

Az inflációs ráta 1988 utáni emelkedésében, a leértékelések mellett nagy szerepe volt annak, hogy adómentesen lehetett emelni a kereseteket egy meghatározott limitig. Ez a korlát a „hozzáadott érték/foglalkoztatott létszám” mutató éves növekedésének a fele volt, azaz, ha a cégnél évi 20\%-kal nőtt az egy dolgozóra jutó hozzáadott érték, akkor 10\%-os béremelés esetén nem volt külön terhe a cégnek. Mivel a keresleti oldalon ritkán ütköztek a versenytársak 
ellenállásába, ezért a vállalatok széles köre élt az olyan inflációs áremeléssel, amelyik a vállalat hozzáadott értékének növelését, és ezzel magasabb kereseti szint elérését eredményezte. Az 1985 utáni két-három évben az ország dollárban kifejezett külső adóssága csaknem a duplájára emelkedett az adósságállományon keletkezett tetemes árfolyamveszteség miatt.

1988-1990-ben évente 2\%-kal csökkent a foglalkoztatottak száma. A beruházások trendje csökkenő volt, kiváltképp 1990-től, a beruházási ráta csak 20\% körüli volt. A stagnáló ipari termelés 1990-re átfordult csökkenésbe. 1990-ben enyhe pozitívumot mutatott a folyó fizetési mérleg, mert az ún. NEO (net errors and omissions: tévedések és kihagyások) sorban 700 millió dolláros többlet szerepelt (a lakosság által, engedély nélkül átváltott valuta értéke jelent meg ebben a NEO-számban).

A kormány 1988 közepén csomagtervvel lépett elő, melyben a liberalizációnak nagy szerepet szánt, az ún. „A” változatú gazdaságpolitikai változatban.

\section{UTÁNI IDŐSZAK}

A 90-es évek legelején pozitív volt a magyar fizetési mérleg azért, mert a fizetési nehézségek miatt kényszerexportra kényszerültek a vállalatok. Pár év alatt azonban megemelkedett a külkereskedelmi hiány. Egyrészt a szovjet utódállamok felvevőpiacának a fizetésképtelensége miatt, másrészt beérett az 1992. évi csőd és felszámolási hullám hatása: sok exportkapacitás kiesett. Ugyanakkor az államháztartási deficitet megemelte a magas kamat, amelyet az államnak az általa kényszerből átvett követelések ${ }^{16}$ után kellett fizetnie. Az 1993-1995 évi ikerdeficit egyenes úton vezetett egy kiigazítási csomaghoz. A Bokros program (1995) a kiadások drasztikus visszafogása miatt nagy áldozatot követelt. Hatására a költségvetési deficit csökkent, a leértékelés és az importilleték pedig a külkereskedelmi hiányt mérsékelte.

A 90-es évek legvégén a FÁK (Független Államtok Szövetsége) országok fizetésképtelensége vezetett nagyobb külkereskedelmi deficithez. 2002-től a Medgyessy-kormány túlzott költekezése miatt megugrott az államháztartás deficitje. Ezzel egyidőben a 2001. évi forint felértékelődés, illetve a béremelések és a lakossági hitelezés felfutása megemelt importigényt jelentett. Ezért 2004-2006-ra ismét egy klasszikus ikerdeficit alakult ki. A 2006. évi ún. „öszödi programmal" ugyan a kirívó hiány valamelyest csökkent, de a pénzpiacokról már nem lehetett hitelt felvenni. Ezt betetőzte a 2008 szeptemberi spekulációs támadás a forint ellen. A teljes államcsődöt csak egy gyors és masszív (25 milliárd eurós) IMF-EU hitelcsomaggal lehetett elkerülni. A 2009-es válság idején a külkereskedelmi hiány csökkent. Az IMF sugallta viszszafogás, majd a 2010-es Orbán-kormány szigorú kiadási politikája miatt az államháztartási deficit is fokozatosan csökkent. A 2010-es évek közepére jelentős fizetési mérleg többlet alakult ki, amely azonban nullszaldó körüli értékre váltott 4-5 év alatt a 2016-utáni évek béremelkedése végett felfutó importkereslet miatt. A pandémia miatt 2-3 évben (2000-2022) magas az államháztartási deficit. A fizetési mérleg azonban nullszaldó körüli maradt, de ezen belül a külkereskedelmi többlet növekedett, míg a turizmus nettó devizahozama jelentősen esett ${ }^{17}$. 
5. ábra: Magyarország államháztartási és folyó fizetési mérleg egyenlegei a GDP \%-ában 1990 és 2020 között

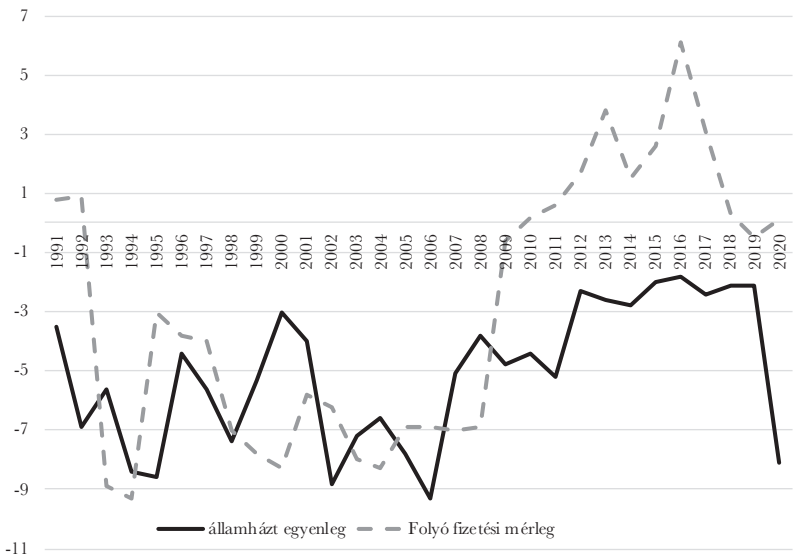

Forrás: ÁSZ $M N B$

A környező sorstárs országok közül sok el volt adósodva a 80-as évek végég. Sokak szerint az adósságválság és az azzal járó infláció volt az utolsó csepp abban a pohárban, amely miatt Jugoszlávia részeire esett szét 1991-ben. Lengyelország számára 1991-ben bejelentették a hitelei 40\%-ának az elengedését és 1993-ban Bulgária adósságán is csökkentettek. 2003-ban Szerbia adósságának a nagyobb hányadát elengedték. Ha valaki azt keresi, hogy Magyarországnak most miért magasabb az adóssága, mint a sorstárs országok legtöbbjének, akkor ennek az a legfontosabb oka, hogy a mi külső adósságunkból soha semmit nem engedtek el, - nem úgy, mint pl. a lengyeleknél és a bolgároknál. Az EU-ba való belépést követően a volt szocialista országok zömében egy másik mutató is jelentős szerepet kapott a nettó devizahelyzet változásának az értékelésre. Ez az ún. külső finanszírozási képesség, amely a folyó fizetési mérleg mellett tartalmazza a nettó transzferegyenleget is. Az EU-tól érkező nettó transzferek értéke átlagosan sokszor eléri a GDP 2-2,5\%-át, ami javítja az adott ország devizális helyzetét ${ }^{18}$.

\section{KÖVETKEZTETÉSEK}

A 70-es és 80-as évtizedben Magyarországon szorosan együtt mozgott a költségvetési deficit és a folyó fizetési mérleg hiánya. Az egyensúly drasztikus felborulása a 70-es évtized második felében nem volt véletlen. A belső felhasználás 60\%-át kitevő lakossági fogyasztást, a közösségi kiadásokat és a dinamikus lakásépítést az akkori vezetés tabuként kezelte, amelyeket nem érinthetnek érdemben a visszafogások. De a többi területen is csak „fél szívvel” csökkentették a belföldi felhasználást, a beruházások 1976. évi visszafogását ismét két év gyors emelkedése követett, a reálbérekben a 1976. évi kisebb növekedést újra magasabb emelkedés követett. ${ }^{19}$ Ráadásul sok esetben gazdaságot serkentő intézkedéseket is meghoztak, ilyen volt a beruházások növelése - leginkább a központi fejlesztési programoknál, de más vállalati területeken is. Másrészt 1980-ig érdemben nem nyúltak hozzá az akkor viszonylag liberális vállalati im- 
portgazdálkodási rendszerhez. Ilyen politika mellett a külkereskedelmi hiány magas volt, az „egyenlegező tétel” a külföldi hitelfelvétel lett.

Jelen tanulmány elején feltett „tyúk vagy tojás” kérdésre az a válasz adható, hogy a beruházások ciklikus megugrása volt a közös ok a külkereskedelmi és a költségvetési hiány növekedése mögött. Az élénkülő beruházások, a termelés növekedése több importot igényelt. A másik oldalon pedig a beruházások finanszírozása a költségvetés hiányát is megemelte. A ciklus következő periódusában beruházások visszafogásával mérsékelhető volt a behozatal, és a költségvetési kiadások is csökkenhettek. A költségvetés pozícióját javította az is, hogy az áremelésekkel megelőzték a fogyasztói ártámogatások terhének a növekedését. A külkereskedelemben gyorsabban javult az egyenleg, míg a költségvetési pozíció javítása ennél hosszabb időt igényelt.

\section{JEGYZETEK}

1 Hét év esetében, lásd Pénzügyminisztérium Részletező adatok a költségvetés végrehajtásához.

2 Ezért nem tudjuk elemezni azt sem, hogy az adott év hiánya mögött mekkora volt az ún. elsődleges deficit, és mekkora a pénzügyi tételek miatti hiány.

3 A fejlődő országoknak gyakran kormányhiteleket adott a magyar fél.

4 Ez akkor 6-8\%-os reálkamatokat eredményezett.

5 Különbözeti termelői forgalmi adó. A kőolaj esetében pl. forintra átszámolt rubelár jelentősen elmaradt a világpiaci ár szintjére beállított belföldi ártól, a kettő különbözetét vonta el ez az adó.

6 1981-től minden költségvetési kapcsolatban a bruttó elszámolásra tértek át. Az összehasonlíthatóság érdekében az 1980-as évre két adatot adott meg a KSH.

$7 \quad$ PM Részletező adatok a költségvetés végrehajtásához 1971, 1974, 1987.

8 Ezenfelül minden forintleértékelés mértékével megemelkedett az adósság állománya 1984-től.

9 Ha például a kivitel 10\%-kal nőtt, és a behozatal 10\%-kal csökkent, akkor az előbbi a GDP 0,4-0,6\%-át jelentő kiadást igényelt, a vámbevételek stb. kiesése pedig a GDP 0,4\%-ára rúgott, azaz együttesen közel 1 százalékponttal rontották a költségvetés hiányát. Ehhez hozzáadódott a következő év(ek) hatása, de a második és harmadik évben a külkereskedelmi javulás általában már ennél mérsékeltebb volt.

10 Lóránt Károly szerint a behozatal 60\%-a a termelés közvetlen célját szolgáló anyag, alkatrész volt. Az ipar importigényessége az 1970 előtti emelkedés után 1970-től már nem változott érdemben, egyik relációban sem.

11 Addig elsősorban az átlagbér-szabályozás dominált, részben azért, nehogy a vállalatok tömegesen bocsássanak el dolgozókat.

12 1985-ben a vállalatok nyeresége nem nőtt kiugró mértékben. A jövedelemcentralizáció azonban csökkent, mert 35\%-ra csökkent a nyereségadó mértéke.

13 Az 1988. évi 20 milliárd Ft állami bevétellel szemben 40 milliárd Ft volt a kiadás, mindenekelőtt az élelmiszerek esetében. A másik oldalon viszont mintegy 60 milliárd Ft körüli volt az éves bevétel az import kütefából a rubelért behozott cikkek után.

14 Pl. az állami és tanácsi finanszírozású beruházások után áfát is kellett fizetni, ehhez a költségvetésben kiadásként oda kellett adni az áfát.

15 E felett a szint felett azonban a béremelés tömege beleszámított a nyereségadó alapjába.

16 Bank és hitelkonszolidáció, rubel követelések, lakáshitelek felének az átvállalása.

17 2021-ben az Audi nagy osztalék-kivétele (6 mrd €) miatt egy évre a folyó fizetési mérleg negatív lett.

18 Tehát például egy átlagosan GDP arányosan 2\%-os folyó fizetési mérleghiány például finanszírozható ebből a forrásból.

19 Hiába vesztette el az ország a külső kapcsolataiban tartósan a GDP-jének 20\%-át. 


\section{Giday András: Kettôs deficit Magyarországon a 70-es és 80-as években}

\section{FelhasZnált IRODALOM}

Állami Számvevőszék (1992): Felentés az állami költségvetési adósság ellenôrzéséról. Állami Számvevőszék, Budapest.

Antal László (1979): Fejlödés - kitérơvel. A Pénzügykutatási Intézet, Budapest.

Barta Imre (1986): A vállalati beruházások döntéselőkészítésének tapasztalatai. Pénzügyi Szemle, 30. évf., 12. sz.

Boda György (1981): A magyar gazdaság importigényességéről. Közgazdasági Szemle, 28. évf., 10. sz., $1148-1163$.

Boda György - Forgon Mária (1988): Az importigényesség alakulása Magyarországon, 1950-1986. KSH, Budapest.

Bródy András (1983): A beruházási ciklus elmélete és szabályozása. Gazdaság, 17. évf., 3. sz., 57-71.

Csikós-Nagy Béla (1983): Az árrendszer továbbfejlesztése. Pénzügyi Szemle, 27. évf., 10. sz., 724-736.

Doros Béláné (1980): A vállalati döntésű beruházási kifizetésekről. Pénzügyi Szemle, 24. évf., 5. sz.

Furceri, Davide - Zdzienicka, Aleksandra (2018): Twin Deficits in Developing Economies. IMF Working Paper, No. $18 / 170$.

Gáspár Pál (1998): Ikerdeficit a magyar gazdaságban. Pénzügykutató Rt., Budapest.

Gidai Erzsébet (1995): A magyar eladósodási folyamat jellemzôi és kiváltó okai. Reális Zöldek.

Hetényi István (1981): A VI. ötéves terv pénzügypolitikájáról. Pénzügyi Szemle, 25. évf., 8-9. sz.

Juhász Jánosné (1982): Hol tartunk a pályamódosításban? Társadalmi Szemle, 37. évf., 8-9. sz.

Kóczián Balázs - Sisak Balázs (2019): Új korszakba léptünk - az 5 legfontosabb tényezö az évtizedes folyó fizetési mérleg többletünk mögött. Magyar Nemzeti Bank, Budapest, www.mnb.hu/letoltes/koczian-sisak-uj-korszakba-leptunk-az-5-legfontosabb-tenyezo-az-evtizedes-folyo-fizetesi-merleg-tobbletunk-mogott.pdf.

Lóránt Károly (1981): Iparpolitika és ipari fejlődés a hetvenes évtizedben. Makrotrend.

Lőkös János (1981): A lakosság jövedelmének és fogyasztásának alakulása. Társadalmi Szemle, 36. évf., 3. sz., 33 -42.

Marinovich Endre (1987): A külkereskedelem tervei és feladatai 1987-ben. Pénzügyi Szemle, 31. évf., 3. sz.

Medgyessy Péter - Szabolcsi János - Kamarás Károly (1980): Az 1980. évi szabályozóváltozások egyes vonásai. Pénzügyi Szemle, 24. évf., 5. sz.

MNB (1993): Külsó eladósodás és adósságkezelés Magyarországon. MNB Mühelytanulmányok, Budapest.

Muraközy László (1987): Gondolatok a költségvetés bevételeiről és kiadásairól. Pénzügyi Szemle, 31. évf., 4. sz.

Pongrácz László (1987): A bér- és keresetszabályozás mai kérdései. Társadalmi Szemle, 42. évf., 7. sz., 11-19.

Pénzügyminisztérium: Részletező adatok a költségvetés végrehajtásához. 1971, 1976, 1984, 1987.

Pulai Miklós - Vissi Ferenc (1984): Munka közben. Társadalmi Szemle, 39. évf., 7-8. sz., 27-39.

Soós Károly Attila (1986): Terr, kampány, pénz. Szabályozás és konjunktúraciklusok Magyarországon és Jugoszláviában. Kossuth Kiadó, Budapest.

Szikszay Béla (1985): Árrendszerünkről. Társadalmi Szemle, 40. évf., 1. sz.

Vígvári András (szerk.) (1990): Adósság. Tanulmányok adósságunk múltjáról, jelenéról és jövơojéról. Szakszervezetek Gazdaságés Társadalomkutató Intézete, Budapest.

Vincze Imre (1981): Árpolitika és pénzügyi szabályozás a VI. ötéves terv időszakában. Pénzügyi Szemle, 25. évf., 6. sz. Wiener György (1985): Vállalati beruházás és jövedelemszabályozás. Társadalmi Szemle, 40. évf., 1. sz., 40-54.

Zala Júlia (1984): Árszintvédelem - dinamikus gazdaság. Társadalmi Szemle, 39. évf., 10. sz., 33-47. 